\title{
How the Internet Affects the Current Tourism Marketing Theory and Practice
}

\author{
A.D.L. Goeltom*, L.A. Wibowo, Ratih Hurriyati, V. Gaffar \\ Universitas Pendidikan Indonesia \\ Bandung, Indonesia \\ *novagoeltom71@upi.edu
}

\begin{abstract}
Concerning with 21 st century, there are a lot of changes in the world, the change in many aspect of life like economic, politic, technology and culture. [1] stated that "Technology will increase". In this new era of 22st century, it is the momentum of the global change called Megatrend. [1] define the change in the following area, such as: (1) from nation states to network (2) from export-led to consumer driven (3) from western influence to the Asia way (4) from government driven to market driven (5) from villages to super cit-ies (6) from labor intensive to high technology (7) from west to east. In addition, cultural concept of people has changed lots to modern people. The Internet presence is one of new technology in the era of 21st century. The Internet affect to all elements of life. Surely the most fascinating aspect of the Internet is freedom, free-dom of knowledge, freedom of information, freedom to exchange opinions. Today the Internet is conceivably the most open and democratic communication system in existence-guaranteeing a wide diversity of opinion.
\end{abstract}

Keywords-Internet; Tourism; Marketing Theory; Marketing Strategy

\section{INTRODUCTION}

The Internet was developed by US government funded research agency Advanced Research Project Agency (ARPA), nearly 30 years ago. Its original purpose was to provide a decentralized, fail-safe connection for military researchers and computer defense networks that could function even in the event of war or other disaster. It grew with remarkable speed as government agencies, university, libraries, and business all set up links to growing network. The Internet has become userfriendly both for individual and for business. The Internet is experiencing growth in terms of number of network connected to it. This growth over the last three years from 1993 and the increasing commercialization have created extreme changes of the Internet. In the past, business activities on the Internet were indeed limited, but also now, not only can business be done on the Internet, it is being done by tens of thousands of business and activities. Therefore there are 30 to 70 million people who have some kind of Internet connectivity. There are number of other commercial network providers competing with the Internet. For an access charge, data can be transmitted via telephone line between the users connected so as to exchange texts, pictures, sounds or using special software, telephone calls be made worldwide for the price of local call. Connected to the system are news agencies, book, and news-paper publishers, libraries, museums, archives, and commercial information suppliers who all feed in the information available.

\section{A. Definition of the internet}

The Internet refers to the physical network that links computers across the globe. It consists of the infra-structure of network servers and communication links between them that are used to hold and transport the vast amount of information on the In-ternet. The Internet enables transfer of massages and transaction between connected computers world-wide [2].

The Internet and other global communication network link together key participants in the value chain of a business; vendor, manufactures, distributors, and customers.

Three powerful worldwide changes have altered the environment of business [3]. The first change is the emergence and strengthening of the global economy. The second change is transformation of industrial economies and societies into knowledge and information based service economies. The third is the transformation of the business enterprise.

\section{B. Emergence of the global economy}

Globalization and information technology also bring new threats to business firms, because of global communication and management system, customer now can shop in a worldwide marketplace, obtaining price and quality information reliably, 24 hour a day. This phenomenon heightens competition and forces firms to play in open, unprotected worldwide markets. To become effective and profitable participants in international market, firms need powerful information and communication system.

\section{Transformation of industrial economies}

Information system is needed to optimize the flow of information and knowledge resources. The productivity of employees will depend on the quality of the systems serving them, management decisions about information technology are critically important to the prosperity and survival of a firm. Therefore the growing power of information technology makes possible new services of great economic value. Credit card use, overnight package delivery, and worldwide reservation systems are examples of services that are based on new information technology.

\section{Transformation of the business enterprise}

The third major change in the business environment is the very nature of the organization and management. There has been a transformation in the possibilities for organizing and managing. The new manager relies on informal commitments 
- The range specialist marketing functions

and networks to establish goals, a flexible arrangement of teams and individuals working in task forces, a customer orientation to achieve coordination among employees, and appeals to professionalism and knowledge to ensure proper operation of the firm.

Figure 1 will show how information technology linking with business environment.

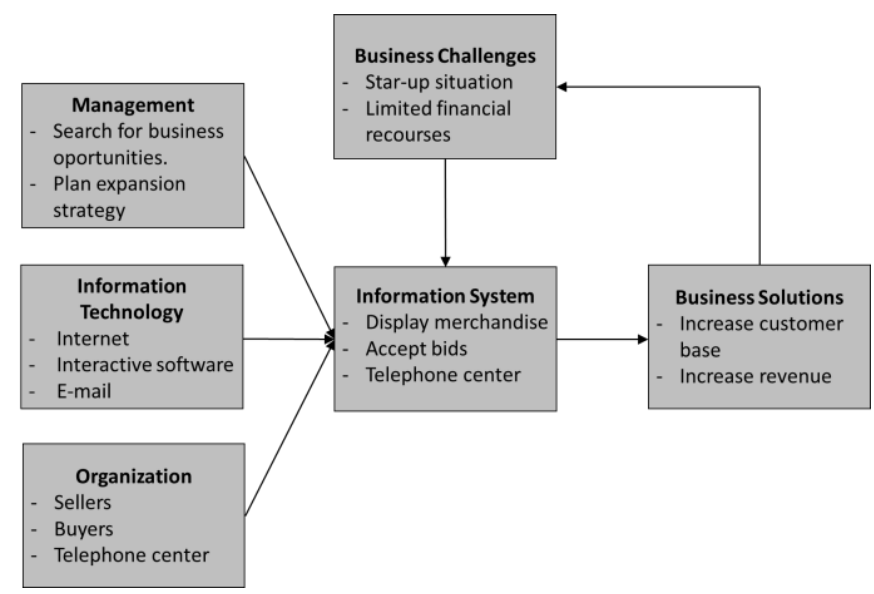

Fig. 1. Information technologies with business environment.

The marketing opportunities of using the Internet can be appreciated by studying the strategic marketing grid [4] for targeting new markets and product. The Internet can be used to achieve each of the four strategic directions as follows:

- Marketing penetration. The Internet can be used to sell more existing products into existing markets. This can be achieved by using the power of the Internet for advertising products to increase awareness of products and the profile of company amongst potential customers in an existing market. This is a relatively conservative use of the Internet.

- Market development. The Internet is used to sell into new markets, taking advantage of the low cost of advertising internationally without the necessity for a supporting sales infrastructure in the customer's country. This is relatively conservative use of the Internet, but it does require the overcoming of the barriers to becoming an exporter on operating in a greater number of countries;

- Product development. New product or service are developed which the Internet can deliver. These are typically information products such as market reports, which can be purchased using electronic commerce. This is innovative use of the Internet.

- Diversification. In this sector, new product are developed which are sold into new market.

- The internet and marketing concept. The word marketing has two distinct meanings in terms of modern management practice. It describes: carried out within many organizations. Such functions include market research, brand / product management, public relations and customer service.

- An approach or concept that can be used as the guiding philosophy for all functions and activities of an organization. Such a philosophy encompasses all aspect of a business. Business strategy is guided by an organization's market and competitor focus and everyone in an organization should be required to have a customer focus in their job.

Modern marketing requires organization to be committed to a market / customer orientation [5]. All parts organization should coordinate activities to ensure that customer needs are met efficiently, effectively and profitably. Marketing encompasses activities traditionally seen as the sole domain of accountants, production, human resources management an information technology.

In the other hand companies can apply the Internet as an integral part of the modern marketing concept since:

- It can be used to support the full range of organizational functions and processes that deliver products and service to customer and other key stakeholders.

- It is powerful communications medium that can act as 'corporate glue' that integrates the different function parts of the organization.

- It facilities information management, which is now increasingly recognized as a critical marketing support tool to strategy formulation and implementation.

- Future role of the Internet should form part of the vision of a company since its future impact will be significant to most businesses.

In addition without adequate information, organizations are at disadvantages with respect to competitors and the external environment. Up to date, timely and accessible information about the industry, markets, new technology, competitors, and customers is a critical factor in an organization's ability to plan and compete in an increasingly competitive marketplace.

The Hi-tech technology's information has produced the utilization of global computer network cultural or known as the Internet to complete the significant information's need for tourist in all over the world.

In tourism industries we can use the Internet for promotion as the marketing tool and the major of it characteristics are:

- Everyone can be a publisher. It is different with offline promotion, online promotion enable everyone can be a publisher, so that everyone including producer can make the site economically. Producer 
- The color full virtual catalogues that consist of text and renewal picture and its renewal is directly to Internet user.

- Well balancing in volume and design. Web tool neutralize interesting design and solid volume so the promotion main key through this tool is neutralizing a big sum of information by giving attention into volume and design better than massage.

- Narrowcasting activity. Marketing and promotion on the Internet is a narrowcasting activity, limited broadcasting and it is not a mass broadcasting. This circumstance caused by one-to-one Internet's tool, so producer gains one person in very moment through the targeting massages.

- Pull activity. Promotion on the Internet is a pull activity so producer has to aim the audience to their web site and make them feel well.

This characteristic helps to create the internet and web as the unique promotion tools and give the challenges to create the Internet and web as the unique promotion tools and give the challenges to producer to think more creative about the Internet utilization as the marketing channel.

\section{E. Advantages}

According to promotion characteristics on the Internet as it mentioned above, enable the internet become a reliable promotion tools with the advantages:

- Enable the information distribution faster, accurately and global.

- Enable the information changes faster according to the need and accessible by a million people around the world directly.

- By using the multimedia presentation tool, promotion on the Internet can be more attract consumer's motivation.

- The shown message on file form and write particularly can push forward the visual form more than words, because file can be consist of colorful draw, film, voice, and interactive programmed.

- Promotion cost in low price compare with sales support delivery.

- Could raise more than 100 million users around the word.

- Information could be access continually everywhere, 24 hours in a whole year.

- By using one of the facility on the internet that is world wide web, promotion on the internet will have a lot of advantages which other media do not have it.

In addition using World Wide Web is a system that causing the data exchange, as mentioned above, could possibility promotion and sales are:
- Product application form on the screen.

- Online support for customer with text, graphs, photo and sound.

- Product distribution announcement and other business are free of charge for printing and sending.

- Comment request and survey form consumers are collected on the file for those users and ready to use anytime.

\section{F. Disadvantage}

- Lack of security. Hacker is a person who gains unauthorized access to a computer network for profit, criminal mischief or persona pleasure. They were charged with breaking into the information system of telephone companies, numerous credit bureaus, and access to bank, stealing telephone service and selling information on how to obtain credit reports. Most recently, alarm has risen over hackers propagating computer viruses, rogue software programs that spread rampantly from system to system, clogging computer memory or destroying program or data. In addition to spreading via computer networks, viruses can invade computerized information system from "infected" diskettes from an outside source, through infected machine, or even from online electronic bulletin boards.

- The consumer will not get the satisfaction because the information is given with the less of human interference.

- There is a possibility that the consumers ignore the appeared information, because of the unwell-known.

\section{METHOD}

The method used in this research is descriptive re-search method. For data collection techniques in this study in the form of observations and other secondary data obtained through study documentation. The analytical techniques used in this study using a qualitative approach, where analysis of the data obtained based on the ability of researchers in combining the facts, information and data obtained by researchers.

\section{RESULTS AND DISCUSSION}

\section{A. How does the internet relate to the marketing mix}

Many practitioners suggest that the marketing mix, the 4Ps, as stated by [6], is an essen-tial part of marketing strategy. It is used as a device to define the marketing tools that should be used to achieve marketing objectives. It has also been extended to include two further elements: people and process [7] although others ar-gue that these are subsumed within the 4Ps.

The advent of the Internet provides opportunities to very element of the marketing mix are follows: 
- Product. The Internet such as specialized market information on subscription can provide new information-based products. Brand variants can be produced for some markets. For example: food and beverage, hotel, package tour, restaurant, etc.

- $\quad$ Price. The product price that offered on the Internet is a real product price in market place and decided by producer. Therefore sales using one of the facilities on the Internet, the price can be arranged more competitive because of low cost on the marketing on line. Alternatively, if a price point can be maintained, the lower cost route to the market can be used to increase profitability.

- Promotion. The World Wide Web message as the promotional tool can be used for advertising, public relation and sales. For example: package tour, destination, airlines, etc.

- $\quad$ Place. The Internet also offers a new sales channel for distributing products through electronic commerce. [8] define "e-commerce as the sharing of business information maintaining business relationship and conducting business transaction by means of telecommunication".

- People. The Internet can be thought of as marginalizing the role of direct customer contact from an organization, but is widely used to help recruit quality staff.

- Processes. The Internet must be integrated with other marketing processes such as telemarketing and direct marketing and different processes of the value chain in order for it to be successful.

It is worth noting that application of the 4Ps can lead to product rather than customer orientation, the later being an important element of Internet Marketing strategy and web site design, [9] suggested that the 4Ps, of customer needs and wants (from the product), cost to the customer (promotion) were important considerations when developing the mix.

\section{CONCLUSION}

The Internet presence is quite a pride, particularly with the tourism business and industry and it has a lot advantages as mentioned above, in addition Internet can make the business and industry of tourism more effectively and efficiently, therefore the presence of Internet can change the marketing environment and the consumer behavior.

But it does not mean it's perfect, technology also still have the weaknesses as mentioned above. In other hand, the Internet is really changing the world performance, so it seems the world become smaller and we can access any information with just one touch.

\section{REFERENCES}

[1] Naisbitt, J. 1995. Megatrends Asia: The eight Asia megatrends which are changing the world. Finlandia: Werner Sodestorm.

[2] Chaffey, D., Mayer, R., Johnston, K. \& Chadwick, F.E. 2002. Internet marketing. England: Prectice Hall.

[3] Laudon, K.C. 1995. Ethical concepts and information technology. Communications of The ACM 38(12): 33-40.

[4] Ansoff, H.I. 1994. Implanting strategic management. Englewood-Cliffs, New Jersey: Prentice Hall.

[5] Jaworski, B.J. \& Kohli, A.K. 1993. Market orientation: Antecedents and consequences. Journal of Marketing 57(3): 53-70.

[6] McCarthy, E.J. 1960. Basic marketing: A managerial approach. Irwin: Homewood

[7] Booms, B.H. \& Bitner, M.J. 1982. Marketing services by managing the environment. Cornell Hotel and Restaurant Administration Quarterly 23(1): 35-40.

[8] Zwass, V., \& Kendall, K. (1999). Structure and macro-level impacts of electronic commerce. Emerging Information Technologies: Improving Decisions, Cooperation, and Infrastructure, Sage, Beverly Hills, CA, 289-315.

[9] Lauterborn, R. 1990. New marketing litany: 4Ps passé; c-words take over. Advertising Age 61(41): 26-28. 